\author{
JURNAL LAMPUHYANG \\ LEMBAGA PENJAMINAN MUTU \\ STKIP AGAMA HINDU AMLAPURA

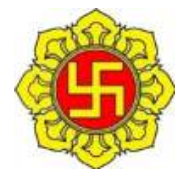 \\ Volume 13 Nomor 1 Januari 2022 \\ p-ISSN: 2087-0760; e-ISSN: 2745-5661 \\ https://e-journal.stkip-amlapura.ac.id
}

\title{
Pembelajaran Jarak Jauh pada Masa Pandemi Covid-19 di Perguruan Tinggi Keagamaan Hindu
}

\author{
I Wayan Jatiyasa \\ STKIP Agama Hindu Amlapura \\ jatiyanz@gmail.com
}

\begin{tabular}{|l|l|l}
\hline Direvisi: 24 November 2021 & Diterima: 12 Desember 2021 & Diterbitkan: 1 Januari 2022 \\
\hline
\end{tabular}

\begin{abstract}
Abstrak: Penelitian ini bertujuan untuk mendeskripsikan bentuk, kendala, dan upaya mengatasi kendala Pembelajaran Jarak Jauh (PJJ) pada masa pandemi Covid-19 di perguruan tinggi keagamaan Hindu. Penelitian ini merupakan penelitian kuantitatif jenis survey. Penentuan subjek penelitian menggunakan nonprobability sampling jenis purposive sampling. Metode pengumpulan data menggunakan metode kuesioner (paperless melalui Google Form) yang disebarkan secara online melalui WhatsApp dan pencatatan dokumen. Metode analisis data menggunakan statistik jenis statistik deskriptif. Berdasarkan hasil penelitian, disimpulkan bahwa: 1) bentuk PJJ pada masa pandemi Covid-19 di perguruan tinggi keagamaan Hindu dominan menggunakan chat, konferensi video, dan asinkron; 2) kendala yang dihadapi dalam penerapan PJJ pada masa pandemi Covid-19 di perguruan tinggi keagamaan Hindu dominan karena masalah jaringan internet, tidak paham materi kuliah, tidak konsentrasi belajar, dan tidak dapat bertanya langsung dengan dosen; dan 3) upaya yang dilakukan untuk mengatasi kendala-kendala penerapan PJJ pada masa pandemi Covid-19 di perguruan tinggi keagamaan Hindu, yaitu mengkondisikan tempat, perangkat digital, waktu, dan pikiran yang baik dalam mengikuti PJJ di perguruan tinggi.
\end{abstract}

Kata Kunci: Pembelajaran Jarak Jauh, Covid-19, Perguruan Tinggi Keagamaan Hindu

Abstract : This study aims to describe the forms, obstacles, and efforts to overcome the obstacles of Distance Learning (DL) during the Covid-19 pandemic at Hindu religious colleges. This research is a survey type quantitative research. Determination of research subjects using nonprobability sampling purposive sampling type. The data collection method used a questionnaire method (paperless via Google Form) which was distributed online via WhatsApp and document recording. The data analysis method used descriptive statistics. Based on the results of the study, it was concluded that: 1) the form of DL during the Covid-19 pandemic at Hindu religious universities was dominantly using chat, video conferencing, and asynchronous; 2) the obstacles faced in implementing PJJ during the Covid-19 pandemic at Hindu religious colleges were dominant because of internet network problems, not understanding course material, not 
concentrating on studying, and not being able to directly ask the lecturers; and 3) efforts made to overcome obstacles to implementing DL during the Covid-19 pandemic at Hindu religious universities, namely to condition good places, digital devices, time, and thoughts in participating in DL in universities.

Keywords: Distance Learning, Covid-19, Hindu Religious College

\section{PENDAHULUAN}

\subsection{Latar Belakang}

Dampak negatif pandemi
Corona Virus Disease (Covid-19) sangatlah serius bagi sektor pendidikan di Indonesia. Pembelajaran yang dulu dilakukan secara tatap muka, secara terpaksa dilakukan melalui Pembelajaran Jarak Jauh (PJJ). Berdasarkan Undang-Undang Perguruan Tinggi Nomor 12 Tahun 2012 Pasal 31 tentang Pendidikan Tinggi bahwa PJJ adalah proses belajar mengajar yang dilakukan secara jarak jauh melalui penggunaan berbagai media komunikasi, sedangkan dalam Peraturan Menteri Pendidikan dan Kebudayaan Nomor 109 Tahun 2013 Pasal 2, dimuat bahwa tujuan PJJ adalah untuk memberikan layanan pendidikan tinggi kepada kelompok masyarakat yang tidak dapat mengikuti pendidikan secara tatap muka, dan memperluas akses serta mempermudah layanan pendidikan tinggi dalam pembelajaran.

PJJ memang pilihan yang tepat pada masa pandemi untuk memutus rantai penyebaran Covid-19. PJJ dapat dilakukan sesuai dengan kemampuan sekolah masing-masing. PJJ dapat menggunakan teknologi digital seperti google classroom, zoom, video conference, telepon dan lainnya. Selain itu juga harus dilakukan pemantauan oleh guru pada saat pemberian tugas melalui grup WhatsApp sehingga siswa benar-benar mengerjakan (Kurniawia, 2021).

PJJ menjadi pilihan yang paling efektif dalam penyelenggaraan pendidikan pada masa pandemi Covid19. Hal ini sesuai dengan hasil penelitian Prawiyogi, dkk (2020), bahwa PJJ cukup efektif dilakukan di SDIT Cendekia Purwakarta. Hal tersebut bisa dilihat dari hasil questioner yang diberikan kepada responden dari 6 pertanyaan yang diajukan hamper semua rata-rata responden mendukung dan menilai bahwa pembelajaran jarak jauh efektif dilakukan terhadap siswa. Meskipun demikian, pelaksanaan PJJ tersebut masih terdapat kendala yakni tidak semua orangtua siswa bisa 
membimbing pembelajaran di rumah karena urusan pekerjaan, sehingga perlu dikoordinasikan secara baik antara guru dengan orangtua kapan pembelajaran atau materi tersebut diberikan kepada siswa sehingga siswa nantinya siap untuk mengerjakan dengan bimbingan orang tuanya di rumah.

Menteri pendidikan dalam Webinar Penyesuaian Kebijakan Pembelajaran di Masa Pandemi Covid19 menyatakan terdapat beberapa kendala yang dihadapi guru, orangtua, dan peserta didik selama PJJ (Mukhlison, 2021).

Kendala penerapan PJJ tidak hanya dialami oleh satuan pendidikan sekolah dasar dan menengah, namun juga di pendidikan tinggi. Hasil survey yang dilakukan oleh Azkiya (2021) terhadap mahasiswa UIN Syarif Hidayatullah Jakarta, Prodi Pendidikan Agama Islam, Semester 1 diketahui beberapa problematika dalam PJJ sebagai berikut. Problematika yang datang dari pribadi mahasiswa itu sendiri seperti sulit memahami materi perkuliahan, hal ini bisa disebabkan karena beberapa faktor seperti mengantuk saat kelas berlangsung, membuka aplikasi lain seperti WhatsApp, instagram, twitter dan media sosial lainnya sehingga mereka tidak fokus dengan apa yang sedang disampaikan oleh dosen atau pemakalah. Penyampaian materi yang monoton pun memicu perasaan bosan mahasiswa, karena hanya terus mendengarkan, tanpa ada interaksi lain. Karena rasa bosen tersebut akhirnya mereka tidak fokus mendengarkan lalu mencari aktivitas lain. Mahasiswa pun kerap kali mengikuti kelas dengan posisi tiduran atau sambil makan, tentu ini bukan tindakan yang baik dalam menuntut ilmu karena suul adab. Dengan tidak pahamnya terhadap materi perkuliahan menyebabkan beberapa mahasiswa kebingungan ketika ada tugas dari dosen, sehingga terkadang mereka menyontek atau menyalin tugas teman, bahkan sampai ada yang dikerjakan oleh orang lain. Selain itu, mahasiswa kerap kali kesulitan dalam membagi waktu, karena tugas yang cukup banyak, sedangkan materi tidak mereka kuasai, sehingga penyelesaian tugas pun menjadi terhambat.

Selain problematika yang datang dari pribadi mahasiswa, problematika pun hadir dari eksternal mahasiswa seperti, jaringan yang tidak stabil dikarenakan tinggal di daerah yang sulit menjangkau sinyal, cuaca yang 
mempengaruhi kualitas sinyal, lalu handphone atau laptop yang tidak berfungsi dengan baik seperti tidak bisa mengaktifkan kamera atau microfon, quota yang cepat habis, mati listrik yang menyebabkan wifi pun mati, jadwal perkuliahan yang mendadak ganti sehingga mengganggu kegiatan lain di luar kuliah bagi segelintir mahasiswa yang mempunyai kegiatan kerja sampingan seperti mengajar, menjadi driver dan lain-lain, dosen yang tidak menjelaskan hanya memberi tugas, dosen yang memberi banyak tugas, teman yang individualis dan tidak bertanggu jawab, kurangnya referensi untuk penugasan, orang tua yang kurang mendukung, seperti terkadang disuruh ketika sedang ada kelas, lingkungan sekitar yang tidak kondusif, seperti banyaknya anak kecil dilingkungan rumah, tetangga yang menyetel musik terlalu keras dan lain sebaginya.

Kendala penerapan PJJ secara online di perguruan tinggi pun ditemukan dalam penelitian Rahmawati (2009: 97-98), bahwa kendala penerapan PJJ secara online, yaitu: (1) ICT pakai jaringan Jardiknas, tidak sebagus koneksi yang lain, kadangkadang error; (2) saat video conference
(Vicon) berlangsung Unnes tidak tersambung dengan Dirjen Dikti; (3) kemampuan mahasiswa dalam bidang ICT masih lemah; dan (4) kesibukan dosen membuat dosen tidak bisa terus menerus duduk di depan internet, sehingga kadang-kadang dosen terlambat membalas inisiasi dari mahasiswa.

Mencermati proses PJJ yang masih terdapat beberapa kendala sebagaimana tersebut di atas, dapat dikatakan PJJ merupakan pembelajaran yang belum ideal. Fenomena ini sangat menarik untuk dikaji lebih mendalam, terutama proses PJJ di perguruan tinggi keagamaan Hindu baik swasta maupun negeri. Penelitian ini mencoba mengkaji PJJ pada masa pandemi Covid-19 di perguruan tinggi keagamaan Hindu, yaitu Universitas Hindu Negeri Ida Bagus Sugriwa Denpasar, STAHN Mpu Kuturan Singaraja, STKIP Agama Hindu Amlapura, dan STHD Klaten Jawa Tengah.

\subsection{Rumusan Masalah}

Mengacu latar belakang di atas, maka permasalahan dalam penelitian ini dirumuskan sebagai berikut.

$$
\begin{array}{ll}
\text { 1.2.1 } & \text { Bagaimanakah } \\
& \text { pembelajaran jarak jauh }
\end{array}
$$


pada masa pandemi Covid19 di perguruan tinggi keagamaan Hindu?

1.2.2 Apakah kendala yang dihadapi dalam penerapan pembelajaran jarak jauh pada masa pandemi Covid19 di perguruan tinggi keagamaan Hindu?

1.2.3 Bagaimana upaya mengatasi kendala-kendala dalam penerapan pembelajaran jarak jauh pada masa pandemi Covid-19 di perguruan tinggi keagamaan Hindu?

\subsection{Tujuan Penelitian}

Mengacu rumusan masalah tersebut di atas, tujuan penelitian ini, yaitu untuk mendeskripsikan bentuk pembelajaran jarak jauh pada masa pandemi Covid-19 di perguruan tinggi keagamaan Hindu, kendala-kendala yang dihadapi, serta upaya untuk mengatasi kendala yang dihadapi dalam pelaksanaan PJJ.

\subsection{Manfaat Penelitian}

Adapun manfaat penelitian ini dibedakan atas manfaat teoretis dan manfaat praktis.
Secara teoretis, penelitian ini diharapkan dapat bermanfaat menambah informasi, wawasan, dan literatur terkait dengan penerapan pembelajaran jarak jauh (PJJ) pada masa pandemi khususnya di perguruan tinggi keagamaan Hindu. Secara praktis, penelitian ini diharapkan dapat bermanfaat bagi pihak-pihak terkait, seperti perguruan tinggi, mahasiswa, pemegang kebijakan, dan peneliti lain.

\section{TINAJUAN PUSTAKA}

\subsection{Pengertian Pembelajaran Jarak}

Jauh

Pembelajaran jarak jauh merupakan pendidikan formal berbasis lembaga, dimana kelompok belajar terpisah dan digunakan sistem komunikasi dalam interaksi (Holden \& Westfall, 2008; Lestari, tt). Pembelajaran jarak jauh dalam pelaksanaannya dapat membuat mahasiswa memiliki keterampilan serta kesempatan lebih besar dalam berinteraksi (Dede, 1991).

Pendapat lain disampaikan oleh Munir (2009: 11), bahwa pada hakikatnya pembelajaran jarak jauh merupakan pendidikan yang berlangsung sepanjang hayat yang berorientasi pada kepentingan, kondisi, 
dan karakteristik pembelajar. Lebih lanjut dikatakan bahwa, pembelajaran jarak jauh merupakan pendidikan terbuka yang memberikan kesempatan kepada siapa saja, pada usia berapa saja, untuk memperoleh pendidikan apa saja, dari sumber apa saja dan dari siapa saja. Pembelajar dapat memperoleh pendidikan di rumah (home based education) yang dibimbing dan dibina oleh orang tua atau anggota keluarga, atau pada lembaga pendidikan non formal. Selain itu, pembelajaran jarak jauh pun terbuka dengan program belajar yang terstruktur, dan pola pembelajaran yang berlangsung tanpa tatap muka atau keterpisahan fisik antara pengajar dengan pembelajar.

Berdasarkan pendapat para ahli tersebut, maka dapat ditarik simpulan bahwa pembelajaran jarak jauh adalah pendidikan formal atau non formal yang berbasis lembaga maupun home based education, secara tertstruktur atau terbuka melalui pola pembelajaran yang berlangsung secara tatap muka dan tanpa tatap muka antara pengajar dengan pembelajar.

\subsection{Pandemi Covid-19}

Covid-19 adalah penyakit menular yang disebabkan oleh jenis coronavirus yang baru ditemukan. Coronavirus adalah suatu kelompok virus yang dapat menyebabkan penyakit pada hewan atau manusia. Beberapa jenis coronavirus diketahui menyebabkan infeksi saluran nafas pada manusia mulai dari batuk pilek hingga yang lebih serius seperti Middle East Respiratory Syndrome (MERS) dan Severe Acute Respiratory Syndrome (SARS). Coronavirus jenis baru yang ditemukan menyebabkan penyakit COVID-19. Virus baru dan penyakit yang disebabkannya ini tidak dikenal sebelum mulainya wabah di Wuhan, Tiongkok, bulan Desember 2019. COVID-19 ini sekarang menjadi sebuah pandemi yang terjadi di banyak negara di seluruh dunia (WHO, 2021).

WHO (World Health

Organization atau Badan Kesehatan Dunia) secara resmi mendeklarasikan virus corona (COVID-19) sebagai pandemi pada tanggal 9 Maret 2020. Artinya, virus corona telah menyebar secara luas di dunia. Istilah pandemi terkesan menakutkan tetapi sebenarnya itu tidak ada kaitannya dengan keganasan penyakit tetapi lebih pada penyebarannya yang meluas. Pada umumnya, virus corona menyebabkan gejala yang ringan atau sedang, seperti 
demam dan batuk, dan kebanyakan bisa sembuh dalam beberapa minggu. Tetapi bagi sebagian orang yang berisiko tinggi (kelompok lanjut usia dan orang dengan masalah kesehatan menahun, seperti penyakit jantung, tekanan darah tinggi, atau diabetes), virus corona dapat menyebabkan masalah kesehatan yang serius (KPC PEN, 2021). Jadi, dapat ditegaskan bahwa pandemi Covid-19 adalah penyebaran penyakit Coronavirus Disease (Covid-19) yang cukup cepat dan sudah terjadi penyebaran antar Negara secara mendunia.

\subsection{Perguruan Tinggi Keagamaan}

\section{Hindu}

Perguruan Tinggi adalah lembaga ilmiah yang mempunyai tugas menyelenggarakan pendidikan dan pengajaran di atas perguruan tingkat menengah, dan yang memberikan pendidikan dan pengajaran berdasarkan kebudayaan kebangsaan Indonesia dan dengan cara ilmiah (Undang-Undang Republik Indonesia Nomor 22 Tahun 1961). Menurut Peraturan Pemerintah Nomor 30 Tahun 1990, dimuat pengertian perguruan tinggi yaitu organisasi satuan pendidikan, yang menyelenggarakan pendidikan di jenjang pendidikan tinggi, penelitian dan pengabdian kepada masyarakat. Perguruan Tinggi merupakan wadah bagi masyarakat kampus. Sebagai suatu organisasi maka perguruan tinggi mempunyai (1) struktur, (2) aturan penyelesaian tugas, yang mencakup pembagian tugas antar kelompok fungsional dan antar warga dalam kelompok yang sama, (3) rencana kegiatan, dan (4) tujuan. Tujuan dibimbing oleh asas dan membimbing rencana kegiatan. Struktur dan aturan penyelesaian tugas menjadi prasarana pencapaian tujuan dan sekaligus mencerminkan asas.

Di Indonesia, perguruan tinggi dapat berbentuk akademik, politeknik, sekolah, institut atau universitas. Program pendidikan dapat berupa diploma (D-1, D-2, D3, D-4), sarjana (S-1), magister (S-2), spesialis (SP 12), dan doctor (S-3) yang diselenggarakan oleh pendidikan tinggi. Perguruan tinggi dapat menyelenggarakan program akademik, profesi dan/atau vokasi. Jadi, perguruan tinggi keagamaan Hindu yang dimaksud dalam penelitian ini ialah lembaga ilmiah yang menyelenggarakan pendidikan dan pengajaran berbasis agama Hindu, meliputi sekolah tinggi (STAHN Mpu 
Kuturan Singaraja, STKIP Agama Hindu Amlapura, dan STHD Klaten Jawa Tengah) dan universitas (UHN IB Sugriwa Denpasar).

\section{METODE PENELITIAN}

Penelitian ini merupakan penelitian kuantitatif jenis survey. Penentuan subjek penelitian menggunakan nonprobability sampling jenis purposive sampling, karena di dalam pengambilan anggota sampel dari populasi dilakukan dengan pertimbangan tertentu. Pertimbangan dimaksud ialah adanya keterwakilan sampel dari perguruan tinggi keagamaan Hindu Negeri maupun Swasta. Dalam hal ini perguruan tinggi keagamaan Hindu Negeri yang dijadikan sampel adalah Universitas Hindu Negeri Ida Bagus Sugriwa Denpasar dan STAH Negeri Mpu Kuturan Singaraja, sedangkan perguruan tinggi keagamaan Hindu Swasta, yaitu STKIP Agama Hindu Amlapura dan STHD Klaten Jawa Tengah. Jenis data yang digunakan adalah data kualitati, dengan sumber data berupa sumber data primer dan sumber data sekunder. Metode pengumpulan data menggunakan metode kuesioner (paperless melalui
Google Form) yang disebarkan secara online melalui WhatsApp dan pencatatan dokumen. Metode analisis data menggunakan statistik jenis statistik deskriptif.

\section{PEMBAHASAN HASIL PENELITIAN}

\subsection{Bentuk PJJ di Perguruan Tinggi Keagamaan Hindu}

Berdasarkan hasil penyebaran kuesioner kepada 203 orang responden dari 4 perguruan tinggi keagamaan Hindu, maka diketahui bahwa PJJ di perguruan tinggi terhitung sampai Juli 2021 masih dilakukan (berlangsung). Selain karena penyebaran Covid-19 yang demikian masifnya, juga karena adanya kebijakan Presiden Republik Indonesia mengenai Pemberlakuan Pembatasan Kegiatan Masyarakat (PPKM) Darurat tanggal 3 Juli 2021 sampai dengan 20 Juli 2021 serta memperhatikan Surat Edaran Menteri Pendayagunaan Aparatur Negara dan Reformasi Birokrasi Nomor 14 Tahun 2021 tentang Penyesuaian Sistem Kerja Pegawai Aparatur Sipil Negara Pada Masa Pemberlakuan Pembatasan Kegiatan Masyarakat Darurat Corona Virus Disease 2019 (Covid-19) di Wilayah Jawa dan Bali. 
Adapun bentuk PJJ pada masa pandemi Covid-19 di perguruan tinggi keagamaan Hindu diuraikan seperti pada tabel 4.1 berikut.

Tabel 4.1 Bentuk PJJ pada Masa Pandemi Covid-19 di PTKH

\begin{tabular}{clccc}
\hline No. & \multicolumn{1}{c}{ Jenis PJJ } & $\begin{array}{c}\text { Jumlah Responden } \\
\text { (orang) }\end{array}$ & Persentase (\%) \\
\hline$(1)$ & \multicolumn{1}{c}{$(2)$} & $(3)$ & $(4)$ \\
\hline 1. & Konferensi Video & & 113 & 55,7 \\
\hline 2. & Pesan Suara (Voice Mail) & & 60 & 29,9 \\
\hline 3. & $\begin{array}{l}\text { Asinkron (penugasan } \\
\text { pertemuan) }\end{array}$ & setiap & 94 & 46,3 \\
\hline 4. & $\begin{array}{l}\text { Jadwal terbuka (lebih } \\
\text { jadwal tidak tentu) }\end{array}$ & bebas, & 46 & 22,7 \\
\hline 5. & Chat (teks) & & 127 & 62,6 \\
\hline
\end{tabular}

(Sumber: Diadaptasi dari Google Form)

Berdasarkan tabel 4.1 di atas, maka dapat dijelaskan bahwa jenis PJJ pada masa pandemi Covid-19 di perguruan tinggi keagamaan Hindu, yaitu sejumlah $55,7 \%$, pembelajaran dilakukan melalui konferensi video, sejumlah $29,6 \% \quad$ pembelajaran dilakukan melalui pesan suara (voice mail), sejumlah $46,3 \%$ pembelajaran dilakukan melalui asinkron (penugasan setiap pertemuan), sejumlah $22,7 \%$, pembelajaran dilakukan melalui jadwal terbuka (lebih bebas, jadwal tidak tentu), dan sejumlah $62,6 \%$ pembelajaran dilakukan melalui chat (teks). Dengan demikian, maka dapat diketahui bahwa jenis pembelajaran yang paling banyak diikuti oleh mahasiswa perguruan tinggi selama pandemi Covid-19 adalah melalui komunikasi secara tertulis (chat), selanjutnya konferensi video, pembelajaran secara asinkron, pesan suara, dan jadwal terbuka. Untuk jelasnya dapat dilihat pada gambar 4.1 di bawah ini. 


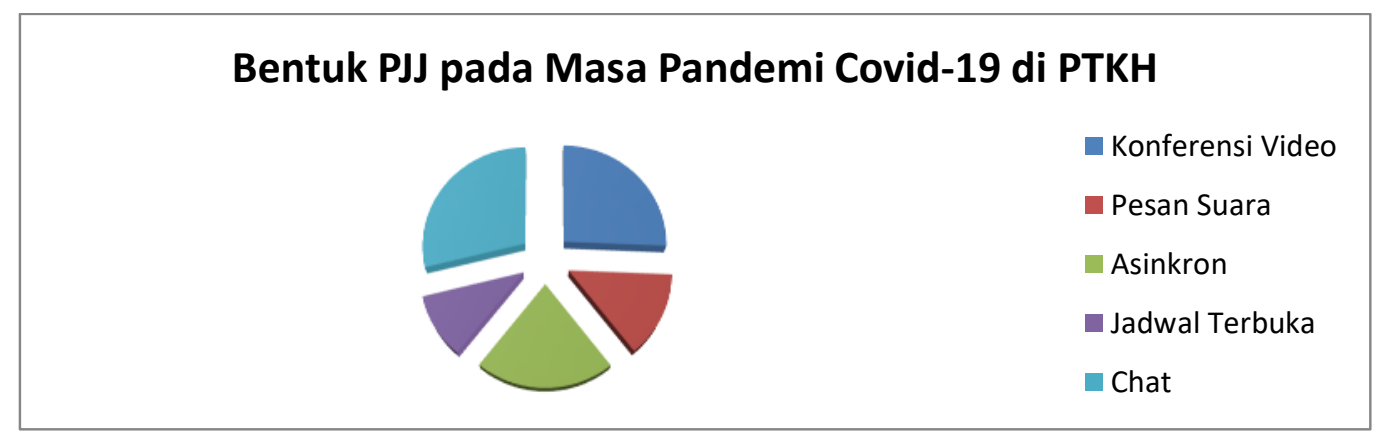

(Sumber: Diadaptasi dari Google Form)

\section{Gambar 4.1 Bentuk PJJ pada Masa Pandemi Covid-19 di PTKH}

Mengacu pada gambar $4.1 \mathrm{di}$ atas, maka yang dimaksud dengan konferensi video adalah pembelajaran yang dilakukan secara langsung (sinkron) melalui platform online yang mampu menampilkan dosen dan mahasiswa dalam waktu bersamaan. Jenis pembelajaran ini dapat berlangsung melalui platform online seperti Zoom dan Google Meet. Dari 203 responden yang mengisi kuesioner, sejumlah $144(70,9 \%)$ orang mahasiswa belajar dengan menggunakan platform online berupa Zoom Cloud Meeting, sedangkan sejumlah 117 (57,6\%) orang mahasiswa belajar menggunakan platform online berupa Google Meet.

Pesan suara (voice mail) merupakan salah satu jenis pembelajaran yang digunakan dosen dalam pembelajaran di kelas daring (dalam jaringan) melalui pengiriman rekaman suara, baik dalam bentuk materi perkuliahan maupun penugasan kepada mahasiswa. Aplikasi yang digunakan mahasiswa dalam belajar dengan pesan suara (voice mail), yaitu WhatsApp (WhatsApp Group/WAG) dan Telegram. Dari 203 responden yang mengisi kuesioner, diketahui bahwa sejumlah 156 (76,9\%) orang mahasiswa berkomunikasi dalam grup WhatsApp $(W A G)$, sedangkan sejumlah $2(1 \%)$ orang mahasiswa menyatakan menggunakan grup telegram untuk berkomunikasi terkait dengan pembelajaran di kelasnya.

Pembelajaran asinkron yaitu pembelajaran yang dilakukan melalui penugasan setiap pertemuan/perkuliahan. Pembelajaran asinkron digunakan oleh dosen untuk memberikan tugas terstruktur agar dikerjakan oleh mahasiswa dengan batas waktu tertentu. Umumnya, penugasan ini dilakukan sebagai tindak 
lanjut dari materi yang sudah diberikan oleh dosennya melalui modul, diktat atau sejenisnya. Tujuan penugasan yakni untuk memberikan pemahaman serta mengeksplorasi pengetahuan mahasiswa terkait dengan topik/masalah yang diberikan oleh dosen. Di samping itu, tugas juga diberikan untuk menilai tingkat pemahaman mahasiswa terhadap materi yang sudah diberikan.

Berdasarkan hasil penyebaran kuesioner kepada 203 responden, maka didapatkan informasi bahwa mahasiswa yang mengikuti pembelajaran secara asinkron melalui platform online, yaitu: sejumlah $181(89,2 \%)$ orang mahasiswa menggunakan Google Classroom, sejumlah $3(1,5 \%)$ orang mahasiswa menggunakan Google Suite for Education, sejumlah 43 (21,2\%) orang mahasiswa menggunakan Youtube, sejumlah $7(3,4 \%)$ oang mahasiswa menggunakan Edmodo, sejumlah 14 $(6,9 \%)$ orang mahasiswa menggunakan Microsoft Teams, sejumlah 1 (0,5\%) orang mahasiswa menggunakan Duolingo, sejumlah 17 (8,4\%) orang mahasiswa menggunakan Quizizz, sejumlah $1(0,5 \%)$ orang mahasiswa menggunakan Kahoot!, sejumlah 1 $(0,5 \%)$ orang mahasiswa menggunakan duo, sejumlah $1 \quad(0,5 \%)$ orang mahasiswa menggunakan e-mail.

Sementara itu, pembelajaran tipe jadwal terbuka yaitu pembelajaran yang lebih bebas, jadwal tidak tentu dan terkadang dilakukan sesuai instruksi dari dosen pengampu mata kuliah masing-masing. Hal ini dilakukan karena adanya halangan atau kendala oleh dosen dan/atau mahasiswa peserta kuliah. Tipe jadwal terbuka ini, umumnya diinformasikan melalui aplikasi WhatsApp (WAG).

Selanjutnya, pembelajaran dengan menggunakan chat yaitu pembelajaran yang dilakukan dengan menyampaikan pesan, materi, prosedur, dan/atau penguatan melalui chat. Platform yang mampu mengakomodir pesan chat, yaitu WhatApp, Telegram, Google Classroom, e-mail, dan yang lainnya.

\subsection{Kendala yang Dihadapi dalam \\ Penerapan PJJ di Perguruan \\ Tinggi Keagamaan Hindu}

Sistem dan pola PJJ
membutuhkan pengelolaan dan
manajemen pendidikan yang khusus
dan baik agar tujuan pembelajaran bisa
terwujud dengan fokus pada kebutuhan
pembelajaran dari pembelajar. Menurut


Munir (2009: 122), salah satu faktor penting untuk keberhasilan PJJ agar bisa berlangsung efektif berasal dari pengajar. Pengajar harus memiliki perhatian, rasa percaya diri, pengalaman, kemampuan menggunakan peralatan dan media, kreatifitas, serta menjalin interaksi dan komunikasi jarak jauh dengan pembelajar. Selain pengajar, faktor lain yang juga penting untuk keberhasilan system PJJ agar bisa berlangsung efektif aalah faktor pembelajar. Pembelajar dianggap penting karena pada saat terjadi proses pembelajaran, pengajar dan pembelajar tidak berhadapan langsung secara tatap muka. Dengan demikian, pembelajar harus mampu aktif dan belajar secara mandiri.

Sehubungan dengan penelitian ini, maka mahasiswa selaku pembelajar harus mampu berproses dan mengembangkan diri dengan pembelajaran yang dilakukan secara jarak jauh. Berdasarkan hasil pengumpulan data melalui kuesioner (paperless via Google Form) yang disebarkan kepada 4 (empat) perguruan tinggi keagamaan Hindu, maka didapatkan data bahwa dari 203 responden, sejumlah $18(8,9 \%)$ orang reponden menyatakan tidak mengalami hambatan dalam mengikuti PJJ pada masa pandemi Covid-19 di kampus mereka masing-masing. Sedangkan sejumlah $185(91,1 \%)$ orang responden lainnya mengalami beberapa kendala, sehingga sering kali pembelajaran yang ditargetkan tidak sesuai dengan tujuan. Kendala yang dihadapi mahasiswa dalam PJJ pada masa pandemi Covid-19 di perguruan tinggi keagamaan Hindu sangat bervariasi. Adapun kendala mahasiswa dalam PJJ dapat dilihat pada tabel 4.2 berikut.

\section{Tabel 4.2 Kendala PJJ pada Masa Pandemi Covid-19 di PTKH}

\begin{tabular}{llcc}
\hline No. & Kendala PJJ & $\begin{array}{c}\text { Jumlah } \\
\text { Responden } \\
\text { (orang) }\end{array}$ & Persentase (\%) \\
\hline$(1)$ & \multicolumn{1}{c}{$(2)$} & $(3)$ & $(4)$ \\
\hline 1. & Jaringan listrik tidak memadai & 5 & 2,5 \\
\hline 2. & Jaringan internet kurang memadai & 161 & 79,3 \\
\hline 3. & Tidak ada quota internet & 65 & 32 \\
\hline 4. & Tidak memiliki perangkat digital & 28 & 13,8 \\
\hline 5. & Terganggu urusan rumah tangga & 38 & 18,7 \\
\hline 6. & $\begin{array}{l}\text { Tidak dapat bertanya langsung } \\
\text { dosen }\end{array}$ & 57 & 28,1 \\
\hline
\end{tabular}




\begin{tabular}{|c|c|c|c|}
\hline 7. & Tidak konsentrasi & 76 & 37,4 \\
\hline 8. & Tidak paham materi & 78 & 38,4 \\
\hline 9. & Tidak ada yang mendampingi belajar & 32 & 15,8 \\
\hline 10. & Tidak dapat bertanya kepada teman & 28 & 13,8 \\
\hline 11. & Lupa jadwal kuliah & 23 & 11,3 \\
\hline 12. & Bosan & 45 & 22,2 \\
\hline 13. & setres & 30 & 14,8 \\
\hline 14. & $\begin{array}{l}\text { Dosen tidak memberikan kuliah tepat } \\
\text { waktu }\end{array}$ & 1 & 0,5 \\
\hline 15. & HP error & 1 & 0,5 \\
\hline
\end{tabular}

(Sumber: Diadaptasi dari Google Form)

Berdasarkan tabel 4.2. di atas, jauh (PJJ) di masa pandemi virus

maka dapat dijelaskan bahwa corona (CNN Indonesia, 2020).

mahasiswa yang mengikuti PJJ selama masa pandemi Covid-19 di perguruan tinggi keagamaan Hindu mengalami 15 jenis kendala. Sejumlah 5 (2,5\%) orang mahasiswa mengalami kendala karena jaringan listrik tidak memadai. Pembelajaran yang dilaksanakan secara langsung/tatap muka (sinkron) melalui video conference yang memanfaatkan jaringan wifi atau internet cenderung tidak dapat dilakukan karena listrik padam. Kondisi membuat mahasiswa tidak mampu mengikuti pembelajaran sebagaimana mestinya. Belum lagi perangkat digital seperti laptop atau Handphone (HP) yang beterainya sudah usang atau daya rendah (low battery) sangat memerlukan listrik secara optimal agar mahasiswa mampu mengikuti pembelajaran secara maksimal. Hal ini penting karena listrik menjadi kelancaran pembelajaran jarak

PJJ pada masa pandemi Covid19 di perguruan tinggi keagamaan Hindu juga terkendala jaringan internet. Sejumlah 161 (79,3\%) orang mahasiswa menyatakan terkendala karena jaringan internet yang kurang stabil. Masalah ini terjadi karena tempat tinggal mahasiswa di daerah blank spot, lemahnya sinyal pada provider yang digunakan, terkendala cuaca, dan geografis mahasiswa di daerah pedalaman. Selain itu, sejumlah $65 \quad(32 \%)$ orang mahasiswa menyatakan terkendala dalam mengikuti PJJ karena tidak memiliki quota internet. Meskipun Kementerian Pendidikan dan Kebudayaan telah memberikan paket quota bagi mahasiswa, namun tampaknya belum secara maksimal dirasakan oleh mahasiswa dalam menunjang aktivitas belajar secara daring. 
Mahasiswa juga mengalami kendala dalam mengikuti PJJ karena tidak memiliki perangkat digital. Sejumlah $28(13,8 \%)$ orang mahasiswa menyatakan terkendala perangkat digital, karena tidak memiliki laptop dan telepon genggam (handphone) android/smartphone yang mendukung pembelajarannya. Sekalipun mayoritas di perguruan tinggi memiliki telepon genggam, namun hanya dimiliki oleh mahasiswa yang lebih muda; mahasiswa eksekutif dengan ekonomi yang terbatas hanya membawa telepon genggam tidak berbasis android. Oleh karena itu, komunikasi dan informasi tentang perkuliahan menjadi terbatas, hanya bisa melalui Short Message Service (SMS) dan telepon saja. Sejumlah $1(0,5 \%)$ orang mahasiswa juga terkendala PJJ pada masa pandemi Covid-19, karena telepon genggam (HP) yang error. Kondisi telepon yang terlalu banyak aplikasi, pesan, dan akses pembelajaran berbasis platform online menjadikan telepon panas dan mudah error.

Aktivitas belajar di rumah, memaksa mahasiswa untuk pintar-pintar mengkondisikan keadaan supaya terhindar dari gangguan. Sekalipun demikian, dalam kondisi pandemi sebagian besar aktivitas masyarakat dilakukan di rumah. Oleh karena itu, bagi mahasiswa yang sudah menikah dan memiliki anggota keluarga yang besar, cenderung terganggu dalam mengikuti PJJ. Sejumlah 38 (18,7\%) orang mahasiswa menyatakan terganggu dengan urusan rumah tangga selama mengikuti PJJ pada masa pandemi Covid-19. Di samping itu, sejumlah $57(28,1 \%)$ orang mahasiswa menyatakan terkendala dalam PJJ karena tidak dapat bertanya secara interaktif dengan dosen pengampu mata kuliahnya.

Selain itu, sejumlah $76(37,4 \%)$ orang mahasiswa juga terkendala dalam PJJ pada masa pandemi Covid-19 karena tidak konsentrasi atau fokus terhadap kuliah yang diikutinya. Mengingat banyaknya tugas-tugas dari dosen pengampu mata kuliah menyebabkan sejumlah $78 \quad(38,4 \%)$ orang mahasiswa juga tidak memahami materi yang diberikan oleh dosennya. Pembelajaran yang dilakukan mahasiswa secara mandiri memerlukan kedisiplinan yang sangat ketat, sehingga tidak aka nada materi kuliah yang tertinggal. Kebiasaan mahasiswa dalam pembelajaran tatap muka di kampus, menyebabkan sejumlah $32 \quad(15,8 \%)$ 
orang mahasiswa merasa terkendala dengan sistem PJJ yang diterapkan di perguruan tinggi, karena mereka tidak mendapatkan pendampingan belajar, baik dari dosen, teman sekelas, maupun orang tuanya. Dengan penerapan PJJ juga sejumlah $28 \quad(13,8 \%)$ orang mahasiswa menyatakan tidak dapat bertanya terkait materi dan tugas-tugas kuliah dengan teman-temannya secara langsung.

Padatnya aktivitas mahasiswa
baik karena kewajiban sebagai
mahasiswa maupun rutinitas hariannya,
menyebabkan sejumlah 23 (11,3\%) orang mahasiswa menyatakan lupa jadwal kuliahnya. Hal ini juga sangat dipengaruhi oleh pergantian jadwal yang berubah-ubah sesuai situasi dan kondisi. Sejumlah $1 \quad(0,5 \%)$ orang mahasiswa menyatakan bahwa ada dosen yang tidak memberikan kuliah tepat waktu. Dengan demikian, mahasiswa kebingungan untuk mengkondisikan kelas yang akan diikutinya.

Penerapan sistem PJJ di perguruan tinggi juga tidak dapat berjalan secara optimal karena sejumlah $45 \quad(22,2 \%)$ orang mahasiswa mengalami kebosanan, sedangkan sejumlah $30(14,8 \%)$ orang mahasiswa mengalami setres. Jadwal pembelajaran yang padat dengan beban tugas dan mengkondisikan pembelajaran sinkron (daring) memerlukan usaha yang tidak sedikit, sehingga mahasiswa mengalami tantangan yang cukup besar dalam mengikuti setiap perkuliahan dari dosen-dosennya.

Jadi, sesuai uraian di atas, maka dapat ditegaskan kembali bahwa kendala-kendala yang dihadapi mahasiswa dalam PJJ pada masa pandemi Covid-19 di perguruan tinggi, dari level tinggi ke rendah, yaitu: (1) jaringan internet kurang memadai; (2) tidak paham materi kuliah; (3) tidak konsentrasi belajar; (4) tidak ada quota internet; (5) tidak dapat bertanya langsung kepada dosen; (6) bosan; (7) terganggu urusan rumah tangga; (8) tidak ada yang mendampingi belajar; (9) setres; (10) tidak memiliki perangkat digital (laptop dan HP); (11) tidak dapat bertanya kepada teman; (12) lupa jadwal kuliah; (13) jaringan listrik tidak memadai; (14) dosen tidak memberikan kuliah tepat waktu; dan (15) HP error. Gambaran secara umum terkait kendala PJJ pada masa pandemi Covid-19 dapat dilihat pada gambar 4.2 berikut. 


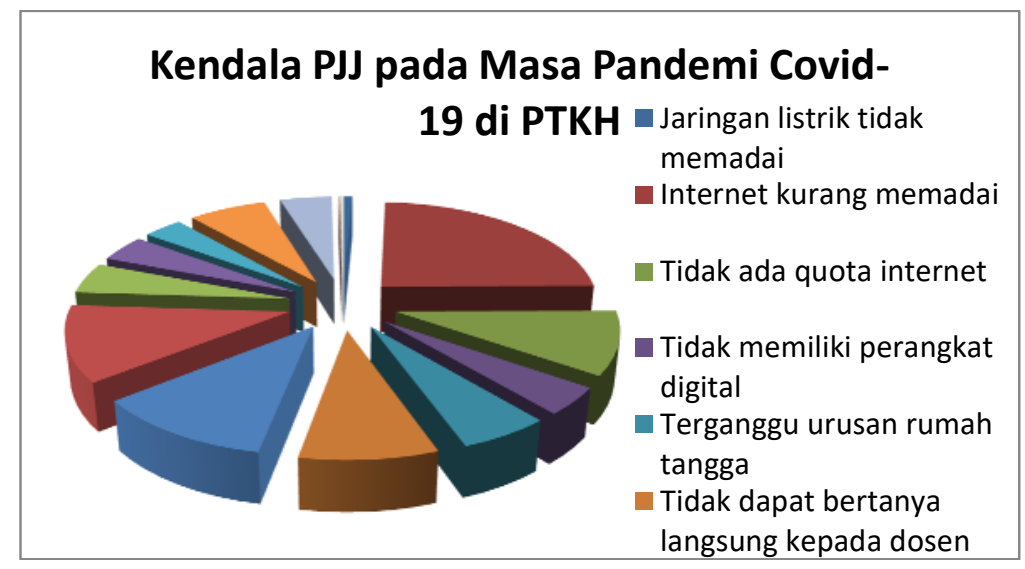

(Sumber: Diadaptasi dari Google Form)

\section{Gambar 4.2 Kendala PJJ pada Masa Pandemi Covid-19}

\subsection{Upaya Mengatasi Kendala}

\section{Penerapan PJJ di Perguruan}

\section{Tinggi Keagamaan Hindu}

Berdasarkan hasil angket (kuesioner) yang disebarkan kepada 203 orang responden, maka diperoleh cara yang dapat dilakukan untuk mengatasi kendala penerapan PJJ pada masa pandemi Covid-19 di perguruan tinggi keagamaan Hindu, yaitu sebagai berikut.

Kendala jaringat internet yang digunakan cenderung lelet, menyebabkan kendala yang sangat serius dalam PJJ baik bagi mahasiswa maupun dosen. Oleh karena itu, upaya yang perlu dilakukan adalah keluar rumah untuk mencari tempat atau areal yang terjangkau sinyal internet. Selain itu, mahasiswa juga dapat memanfaatkan $\mathrm{WiFi}$ gratis yang berada di Balai Banjar setempat, menyewa warnet, minta $\mathrm{WiFi} /$ hotspot di tetangga atau teman. Dalam kondisi seperti itu, dosen selaku pengampu mata kuliah juga harus berlaku adil, menghargai, dan memaklumi mahasiswa yang sedang terkendala internet atau gangguan provider.

Kendala lain yaitu mahasiswa tidak memahami materi kuliah yang diberikan oleh dosen melalui kelas daring, seperti pada Google Classroom, Edmodo, Google Meet, atau Zoom. Upaya yang perlu dilakukan, yaitu: (1) mencari sumber/informasi yang relevan dengan materi kuliah baik di internet, YouTube, buku, modul, maupun pustaka lain; (2) mahasiswa bertanya kepada dosen pengampu mata kuliah dengan memanfaatkan media sosial yang ada (chat WhatsApp, telepon, messenger, 
dan sejenisnya); (3) dosen harus lebih kreatif dan inovatif dalam menyajikan materi kuliah dan memberikan tugastugas kepada mahasiswa, agar terwujud pembelajaran yang lebih bermakna, menginspirasi, dan menyenangkan; (4) mahasiswa wajib mempelajari materi yang diberikan oleh dosen; (5) menggunakan model, pendekatan, metode, dan teknik pembelajaran yang bervariasi serta aplikasi/platform dan instrument penilaian yang beragam; an (6) dosen memberikan perhatian secara khsusus bagi mahasiswa yang jarang mengikuti perkuliahan daring.

Kendala lain yang dihadapi dalam PJJ pada masa pandemi Covid-19 ialah mahasiswa tidak dapat berkonsentrasi dalam belajar. Hal ini dapat disiasati dengan berusaha tempat dengan suasana yang sepi dan nyaman. Di samping itu, berusaha semaksimal mungkin untuk menenangkan pikiran disertai doa.

Kendala tidak adanya quota internet selama mengikuti PJJ dapat dilakukan secara mandiri oleh mahasiswa bersangkutan. Sebelum mengikuti pembelajaran secara daring, mahasiswa wajib menyiapkan paket atau quota internet yang cukup. Quota internet yang telah diberikan oleh
Kementerian Pendidikan dan Kebudayaan disalurkan melalui perguruan tingginya masing-masing mesti dimanfaatkan untuk kepentingan belajar. Paket internet tersebut diharapkan dapat tetap diberikan kepada mahasiswa yang terdampak Covid-19 secara menyeluruh dan berkelanjutan.

Kendala tidak dapat bertanya langsung kepada dosen. Hal ini dapat diatasi dengan bertanya kepada dosen secara langsung melalui jaringan pribadi (japri) dengan memanfaatkan media yang ada seperti telepon, SMS, atau chat WhatsApp. Mahasiswa jangan merasa malu dalam bertanya demi kemajuan belajarnya. Sekalipun berkomunikasi menggunakan perangkat digital, namun perlu diperhatikan etika dalam berbicara, yaitu sopan santun dalam bertanya dan menanggapi jawaban dosen.

Lamanya penerapan PJJ di perguruan tinggi keagamaan Hindu karena pandemi Covid-19 menyebabkan kebosanan dan setres di kalangan mahasiswa. Oleh karena itu, upaya yang perlu dilakukan untuk menghilangkan kebosanan, yaitu: (1) menghilangkan kejenuhan dengan mendengarkan lagu atau music kesukaan; dan (2) menonton film atau video kesukaan seperti drama 
korea. Sedangkan untuk menghilangkan setres dapat dilakukan melalui: (1) pemberian motivasi oleh dosen kepada mahasiswa untuk dapat mengikuti pembelajaran dengan baik dan maksimal; (2) mahasiswa belajar untuk menetapkan target belajar secara mandiri; (3) mohon toleransi kepada dosen pengampu mata kuliah secara langsung agar diberikan penambahan waktu dalam pengumpulan tugas; (4) kampus dapat memberikan toleransi penundaan pembayaran uang semesteran sampai beasiswa mahasiswa mahasiswa cair; (5) kampus perlu mengusulkan beasiswa bagi mahasiswa yang kurang mampu membayar uang semesteran; dan (6) Dirjen Bimas Hindu Kementerian Agama Republik Indonesia mempercepat pencairan bidikmisi untuk mendukung biaya kuliah mahasiswa.

Kendala karena gangguang urusan rumah tangga, dapat disiasati dengan manajemen waktu oleh mahasiswa. Mahasiswa perlu membagi waktu antara kepentingan kampus, kepentingan keluarga, dan masyarakat serta kepentingan lainnya. Dengan pengelolaan waktu yang baik, maka semua masalah dapat diatasi dengan mudah.
PJJ menuntut mahasiswa belajar dan mengembangkan materi kuliah secara mandiri, namun di sisi lain bagi mahasiswa yang tidak terbiasa belajar mandiri, perlu adanya pendampingan dari keluarga, teman sekelas, ataupun dosennya. Oleh karena itu, diperlukan komunikasi yang baik antara mahasiswa dengan keluarga, teman, dan dosen pengampu mata kuliah dalam rangka memperoleh bimbingan belajar. Pendampingan belajar diperlukan untuk memberikan rasa percaya diri, sehingga mahasiswa tersebut akan lebih mantap untuk belajar dan menyelesaikan tugastugasnya.

Jenjang pendidikan tinggi rupanya juga memiliki kendala di bidang teknologi. Sebab ada beberapa mahasiswa yang tidak memiliki telepon genggam berbasis android dan laptop. Oleh karena itu, sebelum mengikuti kegiatan pembelajaran daring, mahasiswa mesti berusaha untuk membeli atau meminjam perangkat digital kepada teman atau sejawat. Jika memang memungkinkan dapat membeli sesuai budget yang ada. Beberapa responden yang memiliki HP ternyata mengeluhkan terjadi kendala saat PJJ karena HP error. Hal ini dapat diantisipasi sebelum mengikuti 
kegiatan, penting bagi mahasiswa untuk mengecek kondisi HP agar dalam kondisi baik dan siap digunakan untuk belajar daring. Jika memungkinkan, saat HP error, mahasiswa tersebut dapat meminjam HP dari orang lain.

Beberapa responden juga menyatakan terkendala dalam PJJ karena lupa dengan jadwal perkuliahannya. Cara mengatasi agar tidak lupa dengan jadwal, mahasiswa dapat membuat jadwal yang dipajang di kamar, disimpan di note telepon genggamnya masing-masing, atau mengatur pengingat aplikasi kalender telepon genggammya. Di samping itu, mahasiswa juga perlu aktif memantau komunikasi yang terjalin di WhatsApp Group (WAG) mata kuliahnya masingmasing.

Beberapa responden yang terkendala karena tidak dapat bertanya kepada teman, dapat diatasi dengan menjalin komunikasi secara inten dengan teman melalui diskusi di WAG.

Kendala beberapa responden menyatakan bahwa dosen tidak memberikan kuliah tepat waktu. Ini dapat diatasi dengan cara mengingatkan kepada dosen tentang jadwal kuliahnya. Sehari sebelum jadwal kuliahnya, mahasiswa melalui Koordinator Tingkat
(Korti) menghubungi untuk mengingat dosen pengampu mata kuliah. Perlu juga ditindaklanjuti terkait dengan tugas, materi kuliah yang akan diberikan, sehingga mahasiswa dapat mempersiapkan diri dengan baik pada pembelajaran yang akan berlangsung.

Kendala jaringan listrik tidak memadai saat pembelajaran daring, ini dapat diatasi dengan menginformasikan kepada teman atau dosen terkait situasi yang terjadi, serta meminta permakluman, selanjutnya mahasiwa meminta informasi terkait materi dan tugas yang diberikan oleh dosen. Serta mengerjakannya dengan baik saat listrik kembali normal.

\section{PENUTUP}

Berdasarkan hasil pembahasan di depan, maka dapat disimpulkan halhal sebagai berikut. Bentuk PJJ pada masa pandemi Covid-19 di perguruan tinggi kegamaan Hindu, yaitu: (1) chat, (2) konferensi video, (3) asinkron (penugasan setiap pertemuan), (4) pesan suara (voice mail), dan (5) jadwal terbuka. Dalam pelaksanaannya tersebut ditemukan berbagai macam kendala baik dari faktor internal maupun eksternal, sehingga mengahruskan PT 
mencari berbagai upaya untuk mengatasi hal tersebut.

\section{DAFTAR PUSTAKA}

Azkiya, Sakina Nur. 2020. "Problematika Pendidikan pada Masa Pandemi di Perguruan Tinggi”. (Online). Dalam URL: https://kumparan.com/sakina-nurazkiya/problematika-pendidikanpada-masa-pandemi-diperguruan-tinggi1umT225GUlx/full. Diakses tanggal 30 April 2021

Dede, C. 1991. The Evolution of Distance Learning: TechnologyMediated Interactive Learning. 123.

Holden, J. T., \& Westfall, P. J.-L. (2008). AN INSTRUCTIONAL MEDIA SELECTION GUIDE FOR DISTANCE LEARNING. 135.

KPC PEN. 2021. "Apa yang dimaksud dengan Pandemi?". (Online). Dalam URL: https://covid19.go.id/tanyajawab?search=Apa $\% 20$ yang\%20d imaksud\%20dengan\%20pandemi. Diakses tanggal 30 April 2021.

Kurniawia, Herna. 2021. "Dampak Pandemi Covid-19 terhadap Pembelajaran Jarak Jauh". (Online). Dalam URL: https://yoursay.suara.com/kolom/ 2021/05/19/163703/dampakpandemi-covid-19-terhadappembelajaran-jarak-jauh. Diakses tanggal 30 April 2021.

Mukhlison. 2021. "Kendala Pembelajaran Jarak Jauh". (Online). Dalam URL: https://www.stitalkifayahriau.ac.id/kendalapembelajaran-jarak-jauh-dan- solusinya/. Diakses tanggal 30 April 2021.

Munir. 2009. Pembelajaran Jarak Jauh berbasis Teknologi Informasi dan Komunikasi. Bandung: Afabeta.

Peraturan Pemerintah Nomor 30 Tahun 1990 tentang Pendidikan Tinggi.

Rahmawati, Septiana Dwi. 2009. "Kendala Pelaksanaan Pembelajaran Jarak Jauh melalui Internet pada Mahasiswa PJJ S1 PGSD Universitas Negeri Semarang”. (Online). Dalam URL:

https://lib.unnes.ac.id/803/1/2106. pdf. Diakses tanggal 30 April 2021.

Surat Edaran Menteri Pendayagunaan Aparatur Negara dan Reformasi Birokrasi Nomor 14 Tahun 2021

Surat Edaran Menteri Pendidikan dan Kebudayaan Republik Indonesia Nomor 4 Tahun 2020 tentang Pelaksanaan Kebijakan Pendidikan dalam Masa Darurat Penyebaran Corona Virus Disease (Covid-19).

Surat Edaran Sekretaris Jenderal Kementerian Pendidikan dan Kebudayaan Nomor 15 Tahun 2020 tentang Pedoman Penyelenggaraan Belajar dari Rumah dalam Masa Darurat Penyebaran Corona Virus Disease (Covid-19).

Undang-Undang Republik Indonesia Nomor 22 Tahun 1961 tentang Perguruan Tinggi.

WHO. 2021. "Pertanyaan dan Jawaban terkait Coronavirus". (Online). Dalam URL: https://www.who.int/indonesia/ne ws/novel-coronavirus/qa/qa-forpublic. Diakses tanggal 30 April 2021. 